\title{
Seasonal influenza vaccination coverage: a multicenter cross-sectional study among healthcare workers
}

\section{Mevsimsel grip aşısı kapsama oranları: sağlık çalışanları arasında çok merkezli kesitsel bir çalışma}

\begin{abstract}
Ayhanim Tumturk $^{1 *}$ (D), Selma Tosun ${ }^{2}$ (D), Ilknur Esen Yıldız ${ }^{3}$ (D), Handan Alay ${ }^{4}$ (D), Duru Mıstanoglu Ozatay ${ }^{5}$ (D), Duygu Mert ${ }^{6}$ (D), Kenan Ugurlu ${ }^{7}$ (D), Ibrahim Mungan ${ }^{8}$ (D), Mustafa Dogan ${ }^{9}$ (D), Busra Ergut Sezer ${ }^{9}$ (D), Merve Sefa Sayar ${ }^{10}$ (D), Secil Deniz ${ }^{11}$ (D), Zehra Karacaer ${ }^{12}$ (D), Mustafa Uguz ${ }^{13}$ (D), Fernaz Yıldız ${ }^{14}$ (D) , Gul Durmus ${ }^{15}$ (D), Fatma Unlu ${ }^{10}$ (D), Yesim Uygun Kızmaz ${ }^{16}$ (D), Sirin Menekse ${ }^{16}$ (D), Nefise Oztoprak $^{17}$ (D), Cagla Karakoc ${ }^{18}$ (D), Nuran Sarı ${ }^{19}$ (D), Melike Betul Ogutmen 20 (D), Cumhur Artuk ${ }^{12}$ (D), Emre Guven ${ }^{21}$ (D), Yasemin Balkan 22 (D), Abdulkadir Daldal 7 (D), Ozlem Mete 22 (D), Meltem Tasbakan ${ }^{23}$ (D), Tansu Yamazhan 23 (D), Deniz Akyol 23 (D), Pınar Ergen 24 (D), Ozlem Senaydın 24 (D), Selda Sayın 25 (D), Rıza Aytac Cetinkaya ${ }^{26}$ (D), Ercan Yenilmez 26 (D), Nurgul Ceran ${ }^{14}$ (D), Serpil Erol ${ }^{11}$ (D), Sinan Ozturk ${ }^{27}$ (D), Ayten Kadanalı 27 (D), Arzu Altıncekic 28 (D), Osman Ekinci ${ }^{29}$ (D), Ozgur Daglı ${ }^{15}$ (D), Hulya Ozkan Ozdemir ${ }^{2}$, Ayse Batırel $^{30}$ (D), Ergenekon Karagoz ${ }^{10}$ (D), Ugur Kostakoglu ${ }^{3}$ (D), Fazılet Duygu ${ }^{6}$ (D)
\end{abstract}

\footnotetext{
${ }^{1}$ Department of Infectious Diseases and Clinical Microbiology, Turkiye Yuksek Ihtisas Training and Research Hospital, Ankara, Turkey

${ }^{2}$ Department of Infectious Diseases and Clinical Microbiology, Izmir Bozyaka Training and Research Hospital, Izmir, Turkey

${ }^{3}$ Department of Infectious Diseases and Clinical Microbiology, Rize University School of Medicine, Rize, Turkey

${ }^{4}$ Department of Infectious Diseases, Nenehatun Maternity Hospital, Erzurum, Turkey

${ }^{5}$ Department of Infectious Diseases and Clinical Microbiology, Dumlupınar University School of Medicine, Kutahya, Turkey

${ }^{6}$ Department of Infectious Diseases and Clinical Microbiology, Dr. Abdurrahman Yurtaslan Oncology Training and Research Hospital,

Ankara, Turkey

7 Department of Infectious Diseases and Clinical Microbiology, Aralik State Hospital, Gaziantep, Turkey

${ }^{8}$ Department of Intensive Care Unit, Advanced Speciality Education and Research Hospital, Ankara, Turkey

${ }^{9}$ Department of Infectious Diseases and Clinical Microbiology, Corlu State Hospital, Tekirdag, Turkey

${ }^{10}$ Department of Infectious Diseases and Clinical Microbiology, Van Training and Research Hospital, Van, Turkey

${ }^{11}$ Department of Infectious Diseases and Clinical Microbiology, Haydarpasa Numune Training and Research Hospital, Istanbul, Turkey

${ }^{12}$ Department of Infectious Diseases and Clinical Microbiology, Gülhane Training and Research Hospital, Ankara, Turkey

${ }^{13}$ Department of Infectious Diseases, Silifke State Hospital, Mersin, Turkey

${ }^{14}$ Department of Anesthesiology and Intensive Care, Haydarpasa Numune Training and Research Hospital, Istanbul, Turkey

${ }^{15}$ Department of Infectious Diseases and Clinical Microbiology, Bursa Yuksek Ihtisas Training and Research Hospital, Bursa, Turkey

${ }^{16}$ Department of Infectious Diseases and Clinical Microbiology, Kartal Kosuyolu Training and Research Hospital, Istanbul, Turkey

${ }^{17}$ Department of Infectious Diseases and Clinical Microbiology Clinic, Antalya Training and Research Hospital, Antalya, Turkey

${ }^{18}$ Department of Infectious Diseases and Clinical Microbiology, Istinye University School of Medicine, Istanbul, Turkey

${ }^{19}$ Department of Infectious Diseases and Clinical Microbiology, Sincan State Hospital, Ankara, Turkey
} 
${ }^{20}$ Department of Nephrology, Haydarpasa Training and Research Hospital, Istanbul, Turkey

${ }^{21}$ Department of Infectious Diseases and Clinical Microbiology, Murat Erdi Eker State Hospital, Ankara, Turkey

22 Department of Infectious Diseases and Clinical Microbiology, Gaziantep University School of Medicine, Gaziantep, Turkey

${ }^{23}$ Department of Infectious Diseases and Clinical Microbiology, Ege University Faculty of Medicine, Izmir, Turkey

${ }^{24}$ Department of Infectious Diseases and Clinical Microbiology, Istanbul Medeniyet University, Göztepe Training and Research Hospital, Istanbul, Turkey

${ }^{25}$ Department of Research and Development Center, Izmir Bozyaka Training and Research Hospital, Izmir, Turkey

${ }^{26}$ Department of Infectious Diseases and Clinical Microbiology, Sultan Abdülhamid Han Training and Research Hospital, Istanbul, Turkey

${ }^{27}$ Department of Infectious Diseases and Clinical Microbiology, Umraniye Training and Research Hospital Istanbul, Turkey

${ }^{28}$ Department of Infectious Diseases and Clinical Microbiology, Ordu University School of Medicine, Ordu, Turkey

29 Department of Anesthesiology and Intensive Care, Umraniye Training and Research Hospital, Istanbul, Turkey

${ }^{30}$ Department of Infectious Diseases and Clinical Microbiology, Kartal Lutfi Kırdar Training and Research Hospital, Istanbul, Turkey

* Corresponding author: Ayhanim Tumturk E-mail: ayhanim06@yahoo.com.tr ORCID: 0000-0002-0653-6725

Received: 2 November 2019 Accepted: 1 December 2019

\section{ABSTRACT}

Aim: The aim of this study is to evaluate the attitudes of healthcare workers against seasonal influenza vaccine and the reasons for vaccine avoidance.

Materials and Methods: This national survey was conducted from April 1 st to June 30th in 2017. The study was carried out among health care workers working in primary, secondary and tertiary care settings. A total of 12 questions were sent to 5046 health care professionals from 55 different cities who agreed to participate in the survey.

Results: $7 \%$ of the participants stated that they get vaccinated regularly every year. $65.8 \%$ of the participants stated that they don't get vaccinated at all. The most important reason for those who did not receive influenza vaccination was their disbelief in the necessity of the vaccination (51.9\%). The most common reason for the seasonal influenza vaccination was the prevention of influenza infection (56.7\%).

Conclusion: The results of the study showed that HCWs influenza vaccination rates are very low. Doctors have been found to have slightly better rates than other HCWs. The high level of education and the increase in professional experience had a positive effect on the vaccination rate. It is important to know the HCWs attitudes and behaviors towards the vaccination to increase the rates.

Keywords: seasonal influenza vaccination, healthcare workers, attitudes

\section{öz}

Amaç: İnfluenza tüm dünyada önemli ölçüde morbidite, mortalite ve maliyet yükünden sorumludur. Sağlık çalışanları (HCP) mesleksel bulaş açısından risk altındadırlar. Bu çalışmada sağlık çalışanlarının mevsimsel influenza aşısına karşı tutumlarının ve aşıdan kaçınma nedenlerinin değerlendirilmesi amaçlanmıştır.

Gereç ve Yöntem: Bu çok merkezli ulusal anket çalışması 1 Nisan-30 Haziran 2017 tarihleri arasında gerçekleştirildi. Ankete katılmayı kabul eden 55 şehirden toplam 5046 HCP uzaktan katılım yoluyla cevaplamaları için toplam 12 sorudan oluşan bir anket gönderildi.

Bulgular: Çalışmaya katılanların \%7'si her yıl düzenli olarak aşı yaptırdığını belirtti. Hiç yaptırmıyorum diyenlerin oranı \%65,8 idi. Influenza aşışını yaptırmayanların en önemli nedeni grip aşısının gerekliliğine inanmama idi (\%51,9). Mevsimsel grip aşıSı yaptıranların en önemli gerekçesi grip infeksiyonundan korunma $(\% 56,7)$ idi.

Sonuç: Sonuçlarımız, tüm HCP influenza aşılama oranlarının çok düşük olduğunu göstermiştir. Doktorların diğer HCP'lerden biraz daha iyi oranlara sahip olduğunu görülmüştür. Eğitim düzeyinin yüksek olması ve mesleki tecrübenin artması aşılama oranını olumlu yönde etkilemiştir. Sağlık çalışanlarının aşılanma oranlarının artırılabilmesi için öncelikle aşı konusundaki tutum ve davranışlarının bilinmesi gerekir.

Anahtar kelimeler: mevsimsel inluenza aşısı, sağlık çalışanları, tutumlar 


\section{INTRODUCTION}

Influenza is a contagious viral infection with short-term incubation time, mostly transmitted via droplets and causing systematic symptoms such as fever, muscle pain, body aches, headache and fatigue [1]. Seasonal influenza causes an estimated 3 to 5 million cases of severe illness worldwide, with approximately 250,000 to 500,000 casualties each year [2]. The Center for Disease Control and Prevention (CDC) has been recommending that all healthcare workers have received influenza vaccines since 1981 [3]. European guidelines also recommend vaccination of all patient care staff, including health workers, to protect high-risk patients [4]. In the USA, influenza vaccination rates reached $75.2 \%$ in $2013-14$ season due to the determination of influenza vaccine coverage as a performance criterion and mandatory vaccination policies, while this rate is still around $30 \%$ in Europe [5]. Although free influenza vaccination has been provided to healthcare workers in Turkey since 2002, vaccination rates are not yet at the desired level [6-8].

This national multicenter study was conducted to determine the influenza vaccination rates and HCWs beliefs and attitudes towards influenza vaccine. Our study was conducted among HCWs working in primary, secondary and tertiary health care facilities in 55 different cities. Therefore, it is important to give an idea about attitudes toward influenza vaccination at a national scale, due to the high number of samples.

\section{MATERIALS AND METHODS}

This national multicenter survey was conducted from April 1 st to June 30th in 2017. A total of 12 questions were sent to 5046 health care professionals from 55 different cities who agreed to participate in the survey. Each participant filled out the questionnaire anonymously. The health personnel who wanted to participate in the study were asked to complete the questionnaire to determine their demographic characteristics and attitudes towards seasonal influenza vaccine.

\section{Ethics Committee Approval}

This study was done with the approval of the Ethics Committe (Izmir Bozyaka Training and Research Hospital, approval number: 08.29.2016/431) along with Turkey Public Health Institution (approval number: 05.03.2016/45202601).

\section{Statistical Analysis}

After all the data were collected, Kolmogorov Smirnov test was used to determine whether the data showed normal distribution. Since normal distribution was not observed
Table 1. Demographic characteristics of health personnel participating in the research

\begin{tabular}{|c|c|c|}
\hline Characteristics & Number (n) & (\%) \\
\hline \multicolumn{3}{|l|}{ Age } \\
\hline $17-29$ & 1762 & 34.9 \\
\hline $30-39$ & 1694 & 33.6 \\
\hline $40-49$ & 1316 & 26.1 \\
\hline$>50$ & 274 & 5.4 \\
\hline \multicolumn{3}{|l|}{ Sex } \\
\hline Female & 3419 & 67.8 \\
\hline Male & 1627 & 32.2 \\
\hline \multicolumn{3}{|l|}{ Profession } \\
\hline Doctor & 1157 & 22.9 \\
\hline Nurse & 1882 & 37.3 \\
\hline Intern Student & 572 & 11.3 \\
\hline Allied Health Staff & 396 & 7.8 \\
\hline Support and Service Staff & 1039 & 20.6 \\
\hline \multicolumn{3}{|l|}{ Education } \\
\hline Ph.D & 3612 & 71.6 \\
\hline College & 1130 & 22.4 \\
\hline Other & 304 & 6.0 \\
\hline \multicolumn{3}{|l|}{ Work Experience } \\
\hline $0-10$ years & 2973 & 58.9 \\
\hline $11-20$ years & 1224 & 24.3 \\
\hline$>20$ years & 849 & 16.8 \\
\hline
\end{tabular}

after this evaluation, it was considered appropriate to use nonparametric tests. All statistical evaluations were performed using SPSS 20 program. Continuous variables mean +/- standard deviation (SD) and categorical variables were expressed as frequency and percentage. The study population was categorized to 3 different groups after their answers to the influenza vaccination questionnaire. Those 3 groups are, "regularly vaccinated", "occasionally vaccinated", and "never vaccinated". Variables and the relationship between these groups were evaluated using Kruskal Wallis test and spearman rho test as appropriate. Several candidate variables identified with univariate analysis and examined using the multivariate logistic regression analysis to determine independent predictors of vaccination. An alpha level of 0.05 was considered significant.

\section{RESULTS}

A total of 5046 individuals, 1627 men (32.2\%) and 3419 women $(67.8 \%)$, participated in the study. The age of the participants varied from 17-67. The mean age of the participants was $34.2(\mathrm{SD}=9.6)$ and the median age was 34 years. This study had 1157 doctors (22.9\%), 1882 nurses (37.3), 572 intern students (11.3\%), 396 allied health staff (7.8\%), and 1039 support and service staff (this includes cleaning staff, patient transport staff, data record staff, office worker, food staff, and security) attended. The demographic characteristics of the health personnel participating in the study are given in Table 1. The mean experience of working 
Table 2. Distribution of the participants who got vaccinated at least once according to the reasons for vaccination

\begin{tabular}{|c|c|c|}
\hline Reason for Vaccination* $^{*}$ & Number (n) & (\%) \\
\hline Being in the Risk Group $^{*}$ & 153 & 8.9 \\
\hline Protection from Influenza Infection & 980 & 56.7 \\
\hline To Protect Their Families & 286 & 16.5 \\
\hline To Protect the Patients & 197 & 11.4 \\
\hline Avoiding the Pandemic & 168 & 9.7 \\
\hline When a Serious Outbreak Occurs & 252 & 14.6 \\
\hline
\end{tabular}

* Percentages were taken from $n=1728$ people. More than one option can be marked

Table 3. Distribution of people who have never received flu vaccines according to the reasons for not being vaccinated

\begin{tabular}{|c|c|c|}
\hline Reasons for Not Being Vaccinated & Number (n) & (\%) \\
\hline Not Seeing Flu Vaccination as Necessary & 1699 & 51.2 \\
\hline Being Against Flu Vaccination & 249 & 7.5 \\
\hline Afraid from Side Effects of the Vaccine & 330 & 9.9 \\
\hline Due to Getting the Flu After the Vaccination & 259 & 7.8 \\
\hline Not Getting the Flu Without the Vaccination & 153 & 4.6 \\
\hline Vaccination is not Mandatory & 415 & 12.5 \\
\hline My Immune System is Strong & 522 & 15.7 \\
\hline
\end{tabular}

*Percenetages were taken from $\mathrm{n}=3318$ participants

between the participants was 10.7 years $(S D=8.6)$, and the median was 9 years (maximum: 45 years, minimum: 1 year). $7 \%(\mathrm{n}=351)$ of the participants stated that they get vaccinated regularly every year. $65.8 \%(n=3318)$ participants stated that they don't get vaccinated at all. The rate of those who reported having it done occasionally was $27.3 \%$ ( $n=$ 1377). The rate of influenza vaccination increased with age
( $p<0.001)$. Men had a significantly higher vaccination rate than women $(p<0.001)$. The most common cause of seasonal influenza vaccination was to be protected from influenza infection. The rate of those who stated that they get vaccinated to protect their patients was $11.4 \%$ (Table 2). The most common reason for those who did not receive seasonal influenza vaccination was that they did not consider the flu vaccine necessary with $51.2 \%$. Table 3 shows the distribution of those who have never received the flu vaccine throughout their lives according to the reasons for not being vaccinated. The rate of people who stated that they don't get vaccinated was higher in women than in men $(p<0.01)$. Again, the rate of the nurses who stated that they don't get vaccinated was higher than any other occupational groups ( $p<0.001$ ). $49.9 \%$ of those who stated that they had regular vaccination every year were doctors ( $p$ $<0.001$ ). The rate of those who stated that they had no vaccination done was found to be significantly lower as the occupational year increased ( $>20$ years). Table 4 shows the distribution of health personnel by influenza vaccination frequency according to demographic characteristics. 15.1\% of the doctors participating in the study stated that they got vaccinated regularly every year $(n=175)$. Doctors had the highest regular vaccination rate among all occupational groups ( $p<0.001)$. The doctors had 52.2\% ( $n=604)$ participants who did not receive any vaccination. $3.9 \%$

Table 4. Distribution of health personnel according to demographic characteristics of influenza vaccination

\begin{tabular}{|c|c|c|c|c|}
\hline & $\begin{array}{c}\text { Regularly vaccinated } \\
n=351(\%)\end{array}$ & $\begin{array}{c}\text { Irregularly vaccinated } \\
n=1377(\%)\end{array}$ & $\begin{array}{c}\text { Never vaccinated } \\
n=3318(\%)\end{array}$ & $\mathbf{p}$ \\
\hline Age & & & & $<0.001$ \\
\hline $17-29$ & $83(23.6)$ & $358(26.0)$ & $1321(39.8)$ & \\
\hline $30-39$ & $121(34.5)$ & $471(34.2)$ & $1102(32.2)$ & \\
\hline $40-49$ & $110(31.3)$ & $461(33.5)$ & $745(22.5)$ & \\
\hline 50 & $37(10.5)$ & $87(6.3)$ & $150(4.5)$ & \\
\hline Age (mean $+<.001-$ Standart Deviation) & $37.2 \pm 9.8$ & $36.2 \pm 9.1$ & $33.09 \pm 9.6$ & \\
\hline Sex & & & & $<0.001$ \\
\hline Female & $186(53.0)$ & $910(66.1)$ & $2323(70.0)$ & \\
\hline Male & $165(47.0)$ & 467 (33.9) & $995(30.0)$ & \\
\hline Job & & & & $<0.001$ \\
\hline Doctor & $175(49.9)$ & $378(27.5)$ & $604(18.2)$ & \\
\hline Nurse & $74(21.1)$ & $535(38.9)$ & $1273(38.4)$ & \\
\hline Intern Student & $23(6.6)$ & $93(6.8)$ & $456(13.7)$ & \\
\hline Allied Health Staff & $16(4.6)$ & $116(8.4)$ & $264(8.0)$ & \\
\hline Support and Service Staff* & $63(17.9)$ & $255(18.5)$ & $721(21.7)$ & \\
\hline Education & & & & $<0.001$ \\
\hline Ph.D & $267(67.1)$ & $1037(75.3)$ & $2308(69.6)$ & \\
\hline College & $68(19.4)$ & $257(18.7)$ & $805(24.3)$ & \\
\hline High School & $6(1.7)$ & $35(2.5)$ & $113(3.4)$ & \\
\hline Primary-Middle School & $10(2.8)$ & $48(3.5)$ & $92(2.8)$ & \\
\hline Experience from Work & & & & $<0.001$ \\
\hline $0-10$ years & $160(45.6)$ & $675(49.0)$ & $2138(64.4)$ & \\
\hline $11-20$ years & $115(32.8)$ & $382(27.7)$ & 727 ( 21.9$)$ & \\
\hline 20 years & $76(21.7)$ & $320(23.2)$ & $453(13.7)$ & \\
\hline
\end{tabular}

* Cleaning personnel, patient transport staff, data record staff, office worker, food staff, security 
Table 5. Factors affecting influenza vaccination rates during the survey period

\begin{tabular}{|c|c|c|c|c|c|c|}
\hline & \multicolumn{3}{|c|}{ Univariate analysis } & \multicolumn{3}{c|}{ Multivariate analysis } \\
\hline Variable & $\mathbf{O R}$ & $\mathbf{9 5 \%} \mathbf{C l}$ & $\mathbf{p}$ & $\mathbf{O R}$ & $\mathbf{9 5 \%} \mathbf{C l}$ & $\mathbf{p}$ \\
\hline Age & 1.03 & $1.03-1.04$ & $<0.001$ & 1.02 & $1.02-1.03$ & $<0.001$ \\
\hline Sex & 1.34 & $1.19-1.52$ & $<0.001$ & 0.95 & $0.82-1.09$ & 0.4893 \\
\hline Doctor & 0.47 & $0.41-0.54$ & $<0.001$ & 1.47 & $1.25-1.72$ & $<0.0001$ \\
\hline Professional experience $>\mathbf{1 0}$ & 0.49 & $0.39-0.61$ & $<0.001$ & 1.37 & $1.07-1.77$ & 0.0128 \\
\hline Educational level of college or higher & 0.91 & $0.71-1.17$ & 0.4719 & 1.17 & $0.88-1.54$ & 0.2624 \\
\hline Regular vaccination & 0.0005905 & 0.00003683 to 0.009466 & $<0.0001$ & $174 \mathrm{E}+009$ & - & 0.9978 \\
\hline
\end{tabular}

$(n=74)$ of the nurses got vaccinated regularly while the rate of the nurses who didn't get vaccinated was $67.6 \%(n=1273)$. The rate of regular influenza vaccination was significantly higher in people with education level of college or above $(n=4742)$, than people with lower education level (high school or lower $(n=154)(p<0.001)$.

Univariate analysis of the data revealed that high vaccination rates were significantly associated with age, gender, being a doctor, working year longer than 10 years, and regular vaccination history. A multivariate analysis of these parameters showed that the vaccination rate was significantly correlated to age (OR 1.02; 95\%Cl: [1.02-1.03]; $\mathrm{p}$ $<0.001$ ) and being a doctor (OR 1.47; 95\% Cl: [1.25-1.72]; $\mathrm{p}$ $<0.0001$ ) (Table 5).

\section{DISCUSSION}

Flu vaccine has been approved in mid-1940s and it is a safe vaccination. HCW influenza vaccination rates has been unacceptably low (45\%), despite the continuous efforts by the government agencies and professional organizations to encourage the use of vaccination [10]. In health institutions, the direct effect of vaccination is to reduce influenza rates in health care workers. The indirect effect is to prevent the transmission of influenza virus to high-risk patient groups by vaccination of HCWs. HCW vaccination can reduce influenza-related morbidity and mortality among both HCWs and patients [9-11,13]. Although vaccination is widely accepted as an effective and low-cost health technology, the phenomenon known as "vaccination hesitation" is spread not only among citizens, but also among healthcare workers, and as a result vaccination rates are continuously decreasing [11]. Unfortunately, working among HCWs while sick is common and plays a key role in transmission of pathogens in health care settings [9]. In a study conducted by Chiu et al. during the influenza season, they found the rate of health workers working as sick to be $40 \%$ and reported that this rate was $63 \%$ among doctors, reaching its highest level [12]. Ahmed et al. found a significant reduction in all-cause mortality (-44 per 1000 patients) in facilities where influenza vaccines were given to healthcare workers
[13]. For all these reasons, health workers are a priority target group in vaccination.

In our study, $7 \%$ of HCWs ( $\mathrm{n}=351$ ) stated that they get vaccinated regularly every year. The participants who stated to not get vaccinated were at a high amount of $65.8 \%$ $(n=3318)$. The rate of those who reported having it done occasionally was $27.3 \%$ ( $n=1377$ ). This study showed low rates of seasonal influenza vaccination among all HCWs. $\mathrm{HCW}$ vaccination rate varies according to different influenza seasons and countries [14]. In a study conducted by Petek et al., the rate of vaccination of health workers with seasonal influenza vaccine was reported as $12 \%$ [15]. Similarly, in a study conducted by Bonaccorsi et al., it was reported that the rate of HCWs stating they were regularly vaccinated was $12.3 \%$ [16]. In another study conducted in Europe, the vaccination rate was reported as $20 \%$ [17]. In a multicentric study of 3454 health workers in Italy, influenza vaccination rate was reported as $14 \%$. Although the vaccination coverage rate was lower than the recommended minimum level, the research found higher vaccination rates among people over 61 years old ( $p<0.01$ ) [11]. In our study, we found that the rate of those who stated that they do not get vaccinated was significantly lower as the working year in the profession increased ( $>20$ years) $(p<0.001)$.

The main reasons for vaccine coverage are awareness of the high risk of infection in the workplace and the desire to protect family members and colleagues. The main barriers to vaccination are the suspicion of vaccine efficacy, fear of side effects, and the belief that healthcare workers are not at high risk of influenza infection [15]. In our study, we found that the reasons for not being vaccinated were: Not thinking it's necessary (51.2\%), thinking their body resistance is strong enough $(15.7 \%)$, and because the vaccine is not mandatory (12.5\%). 9.9\% of the participants stated that they were afraid of the side effects of the vaccine and $7.5 \%$ were against vaccination. In a study conducted by Esposito et al. among health workers related to seasonal influenza vaccine in Italy and the reasons for not getting vaccinated; $45.3 \%$ stated that they were not intimidated by influenza, $29.9 \%$ due to their doubts on the effectiveness of the vaccination, $14 \%$ due to fear of side-effects of the vaccine, and $2 \%$ stated 
that they were against vaccination [17]. The most common reason for vaccination throughout all the studies was reported as self-protection. In our study, the most common reason for having seasonal influenza vaccine was answered as protection from the influenza infection with $56.7 \%$, protecting family and close contacts with $16.5 \%$, and in case of a serious epidemic with $14.6 \%$. The rate of those who stated that they get vaccinated to protect their patients was as low as $11.4 \%$. In a study conducted by Esposito et al., focusing on reasons to get vaccinated, it was reported that $35.2 \%$ were afraid of passing the disease to the patients, $34 \%$ due to the fear of passing the disease to family or close contacts, and $21.5 \%$ due to having elderly or chronic disease [17]. In a study conducted by Gramegna et al., focusing on reasons to get vaccinated, $63 \%$ stated to protect oneself from influenza, 31\% stated to protect their patients, and $\% 6$ stated to protect their household members. Main reasons for vaccine denial were not having enough time $(45 \%)$, concerns about side-affects (22\%), not getting sick often and/or not being afraid of influenza infection (22\%), and not believing the need for vaccination (9\%) [18].

Although vaccination rates were very low in all occupational groups, there was a greater tendency to be vaccinated in the doctor group. In our study, seasonal influenza vaccination rate was $15.1 \%$ among doctors and $3.9 \%$ among nurses. The rate of those who stated that they had no vaccination done was $52.2 \%$ among doctors and $67.6 \%$ among nurses. This finding supports us in preparing special programs suitable for different occupational categories in order to increase vaccine coverage [19]. In the study reported from Turkey, found the rate of regular vaccination to be $15.2 \%$ in the doctor group and reported that the rate of vaccination was low especially among the nurses who are regularly vaccinated [8]. In a study by Wong et al. reported the vaccination rate as $38 \%$ among clinical nurses [20]. In a study reported from Slovenia, the rate of doctors never getting the flu vaccine was reported as $24 \%$ [21].

The present study has strengths and limitations. A major strength of the present study is that it was a multicenter study involving several centers. By contrast, the fact that the data were self-reported constitutes a limitation. Like all interview studies, this research relied on consenting participants, increasing the chance of a biased sample; HCWs who came forward may have been more likely to be unvaccinated HCWs with a more pronounced opinion on this topic.

\section{CONCLUSION}

Healthcare workers (HCWs) are at risk for occupational infection and subsequent disease development for influenza. They may also transfer the disease to patients and close contacts In this national study, our seasonal influenza vaccine rates were low among all HCWs.. In order to increase the vaccination levels of health personnel, it is necessary to increase the information activities before the flu season, and to monitor the vaccination rates annually and to give feedback to the health facilities. In addition, providing easy access to vaccination services, establishing vaccination days and informing health personnel about these days will contribute to the increase in vaccination rates. Since our study includes many health facilities with dissimilar application characteristics and working environments, our results are important for providing an idea on a national scale. Knowing the reservations of health personnel about vaccination will guide the preparation of appropriate strategies and training programs.

\section{DECLARATION OF CONFLICT OF INTEREST}

The authors received no financial support for the research and/or authorship of this article. There is no conflict of interest.

\section{REFERENCES}

1. Dini G, Toletone A, Sticchi L, et al. Influenza vaccination in healthcare workers: A comprehensive critical appraisal of the literature. Hum Vaccin Immunother. 2018 Mar 4;14(3):772-789.

2. Schmid P, Rauber D, Betsch C, et al. Barriers of Influenza Vaccination Intention and Behavior - A Systematic Review of Influenza Vaccine Hesitancy, 2005 - 2016. PLoS One. 2017 Jan 26;12(1):e0170550.

3. Seasonal Influenza (Flu): Influenza Vaccination Information for Health Care Workers [internet]. Atlanta, GA ABD: Centers for Disease Control and Prevention. Available at: https://www.cdc.gov/flu/healthcare workers.htm

4. Dellafiore S, Contarini M, Blasi F, et al. Knowledge and attitudes on influenza vaccination among Italian physicians specialized in respiratory infections: an Italian Respiratory Society (SIP/IRS) web-based survey. J Prev Med Hyg. 2018 Jun 1;59(2):E128-E131. 
5. Ozisik L, Tanriover MD, Altınel $S$, et al. Vaccinating healthcare workers: Level of implementation, barriers and proposal for evidence-based policies in Turkey. Hum Vaccin Immunother. 2017 May 4;13(5):1198-1206.

6. Çiftci $F$, Şen $E$, Demir N, et al. Beliefs, attitudes, and activities of healthcare personnel about influenza and pneumococcal vaccines. Hum Vaccin Immunother. 2018 Jan 2;14(1):111-117.

7. Akan H, Yavuz E, Yayla ME, et al. Factors affecting uptake of influenza vaccination among family physicians. Vaccine. 2016 Mar 29;34(14):1712-8.

8. Asma $\mathrm{S}$, Akan $\mathrm{H}$, Uysal $\mathrm{Y}$, et al. Factors effecting influenza vaccination uptake among health care workers: A multicenter cross-sectional study. BMC Infect Dis. 2016 May 4;16:192.

9. Edmond MB. Mandatory Flu Vaccine for Healthcare Workers: Not Worthwhile. Open Forum Infect Dis. 2019 Apr 17;6(4):ofy214.

10. Perl TM, Talbot TR. Universal Influenza Vaccination Among Healthcare Personnel: Yes We Should. Open Forum Infect Dis. 2019 Apr 17;6(4):ofz096.

11. Genovese C, Picerno IAM, Trimarchi G, et al. Vaccination coverage in healthcare workers: a multicenter crosssectional study in Italy. J Prev Med Hyg. 2019 Mar 29;60(1):E12-E17.

12. Chiu S, Black CL, Yue $X$, et al. Working with influenza-like illness: presenteeism among US health care personnel during the 2014-2015 influenza season. Am J Infect Control2017; 45:1254-8.

13. Ahmed F, Lindley MC, Allred N, et al. Effect of influenza vaccination of healthcare personnel on morbidity and mortality among patients: systematic review and grading of evidence. Clin Infect Dis. 2014 Jan;58(1):50-7.
14. Ryser AJ, Heininger U. Comparative acceptance of pertussis and influenza immunization among healthcare personnel. Vaccine. 2015;33:5350-6.

15. Petek D, Kamnik-Jug K. Motivators and barriers to vaccination of health professionals against seasonal influenza in primary healthcare. BMC Health Serv Res. 2018 Nov 14;18(1):853.

16. Bonaccorsi G, Santomauro F, Porchia BR, et al. Beliefs and Opinions of Health Care Workers and Students Regarding Influenza and Influenza Vaccination in Tuscany, Central Italy. Vaccines (Basel). 2015 Feb 26;3(1):137-47.

17. Esposito S, Bosis S, Pelucchi C, et al. Influenza vaccination among healthcare workers in a multidisciplinary University hospital in Italy. BMC Public Health. 2008 Dec 23;8:422.

18. Gramegna bir, Dellafiore S, Contarini M, et al. Knowledge and attitudes on influenza vaccination among Italian physicians specialized in respiratory infections: an Italian Respiratory Society (SIP/IRS) web-based survey. J Prev Med Hyg. 2018 Jun 1;59(2):E128-E131.

19. Wicker S, Rabenau HF, von Gierke L, et al. Hepatitis B and influenza vaccines: important occupational vaccines differently perceived among medical students. Vaccine. 2013 Oct 17;31(44):5111-7.

20. Wong NS, Lee S, Lee SS. Differing pattern of influenza vaccination uptake in nurses between clinical and long term care facilities setting, 2014-2018. Int J Infect Dis. 2018 Oct;75:8-10.

21. Učakar V, Kraigher A. Acceptance of Seasonal Influenza Vaccination Among Slovenian Physicians, 2016. Zdr Varst. 2019 Jan 21;58(1):47-53. 